The University of Southern Mississippi

The Aquila Digital Community

Master's Theses

Summer 2020

\title{
Non-Religious Employee's Perceptions of Microaggressions and Their Relationship with Job Satisfaction as Moderated by Calling
}

Jessica Schultz

Follow this and additional works at: https://aquila.usm.edu/masters_theses

Part of the Counseling Psychology Commons, Counselor Education Commons, Industrial and Organizational Psychology Commons, Multicultural Psychology Commons, Other Psychology Commons, Other Social and Behavioral Sciences Commons, and the Personality and Social Contexts Commons

\section{Recommended Citation}

Schultz, Jessica, "Non-Religious Employee's Perceptions of Microaggressions and Their Relationship with Job Satisfaction as Moderated by Calling" (2020). Master's Theses. 715.

https://aquila.usm.edu/masters_theses/715

This Masters Thesis is brought to you for free and open access by The Aquila Digital Community. It has been accepted for inclusion in Master's Theses by an authorized administrator of The Aquila Digital Community. For more information, please contact Joshua.Cromwell@usm.edu. 


\title{
NON-RELIGIOUS EMPLOYEE'S PERCEPTIONS OF MICROAGGRESSIONS AND THEIR RELATIONSHIP WITH JOB SATISFACTION AS MODERATED BY \\ CALLING
}

by

\author{
Jessica N. Schultz
}

\begin{abstract}
A Thesis
Submitted to the Graduate School, the College of Education and Human Sciences and the School of Psychology at The University of Southern Mississippi in Partial Fulfillment of the Requirements for the Degree of Master of Arts
\end{abstract}

Approved by:

Dr. Melanie Leuty, Committee Chair

Dr. Emily Yowell

Dr. Richard Mohn

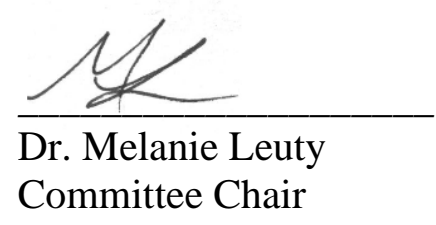

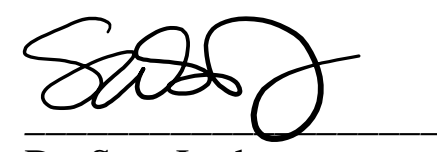

Dr. Sara Jordan Director of School
Dr. Karen S. Coats

Dean of the Graduate School 


\title{
COPYRIGHT BY
}

\author{
Jessica N. Schultz
}

2020

\section{Published by the Graduate School}

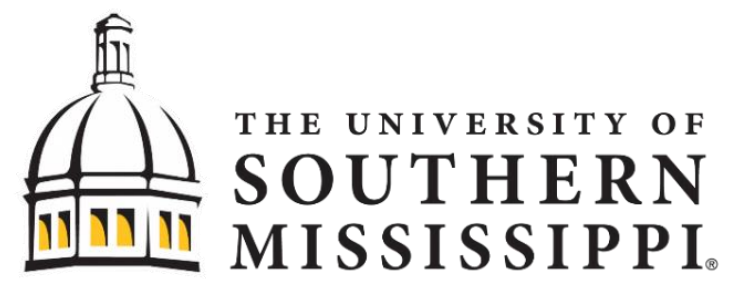




\begin{abstract}
The purpose of this study was to investigate the relationships between microaggressions, person-organization fit (P-O fit), job satisfaction, and calling in nonreligious individuals. Established research demonstrates that job satisfaction is predicted by P-O fit (Dawis, 2005). Research with minority groups has found that microaggressions are negatively related to P-O fit and job satisfaction (Lyons, Velez, Mehta, \& Neil, 2014). However, research has yet to examine these interactions with a non-religious population. Previous investigations have found that calling is positively correlated with both P-O fit and job satisfaction (Duffy \& Dik, 2013; Duffy, Allan, \& Dik, 2011; Hirschi, 2012), suggesting the presence of a calling may mitigate the negative effects of microaggressions on these variables. It was predicted that $\mathrm{P}-\mathrm{O}$ fit would mediate the relationship between microaggressions and job satisfaction and calling would moderate the relationship between microaggressions and $\mathrm{P}-\mathrm{O}$ fit. To examine these relationships, participants were solicited through online communities for non-religious individuals. Results revealed that microaggressions predicted job satisfaction while calling predicted $\mathrm{P}-\mathrm{O}$ fit and job satisfaction. Contrary to previous findings, microaggressions were not significantly related to P-O fit. Thus, P-O fit did not mediate the relationship between microaggressions and job satisfaction. Additionally, calling did not moderate the relationship between microaggressions and P-O fit. Post-hoc analyses revealed that calling was a significant moderator between microaggressions and job satisfaction. Findings expand research on the growing minority of non-religious individuals and contribute to the body of research in calling and offer additional guidance to vocational counselors working with non-religious individuals.
\end{abstract}




\section{ACKNOWLEDGMENTS}

I would like to recognize the invaluable professional and research assistance provided by my committee members and fellow graduate students in counseling psychology and the invaluable emotional assistance provided by my friends and family both here on campus and far away at home. Without your contributions, this work may have never been completed. 


\section{DEDICATION}

I would like to dedicate this work to Mom and Dad. Thank you for your constant support, encouragement, and interest in my research and academic career. 


\section{TABLE OF CONTENTS}

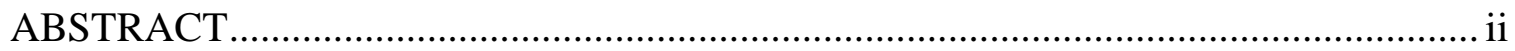

ACKNOWLEDGMENTS .............................................................................. ii

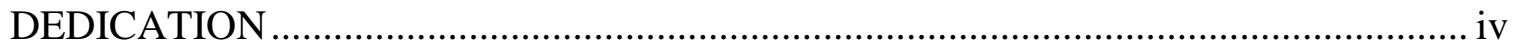

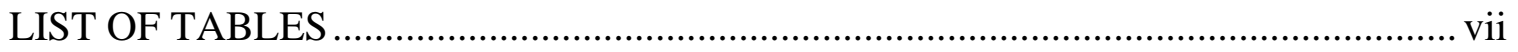

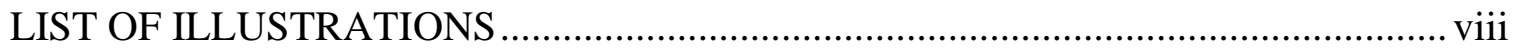

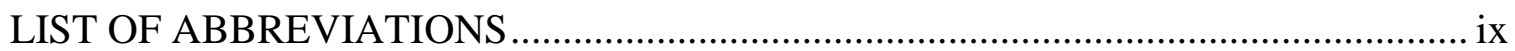

CHAPTER I - LITERATURE REVIEW …...................................................... 1

Non-Religious employees' perceptions of microaggressions and their relationship to

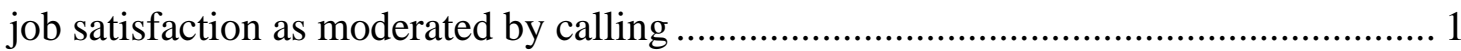

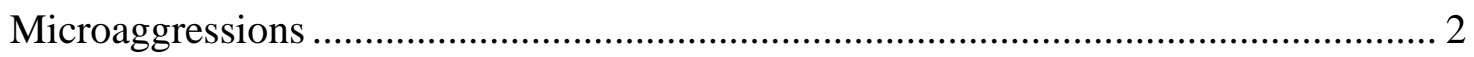

Theory of Work Adjustment.............................................................................. 2

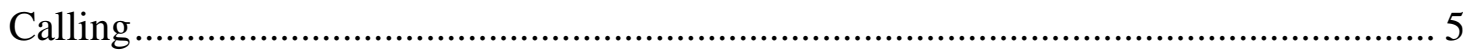

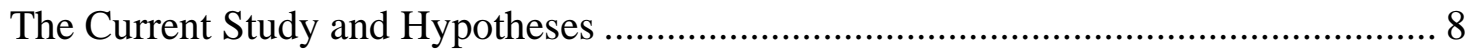

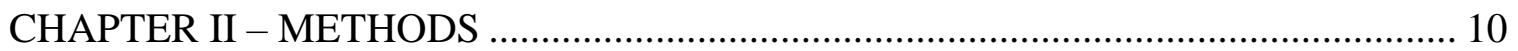

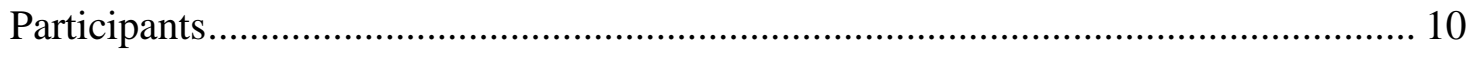

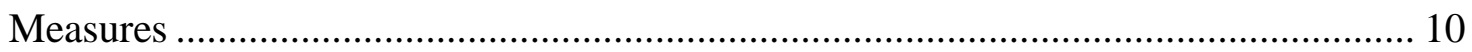

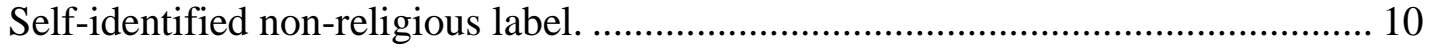

Calling Vocation Questionnaire (CVQ)....................................................... 11

Microaggressions Against Non-religious Individuals Survey (MANRIS)............. 11 
Job Satisfaction. 12

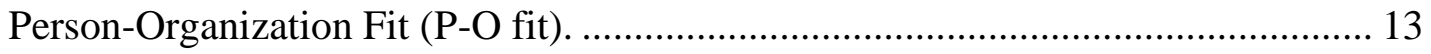

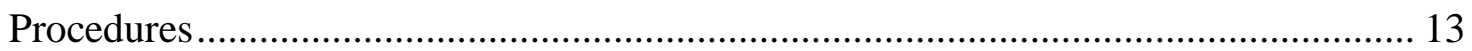

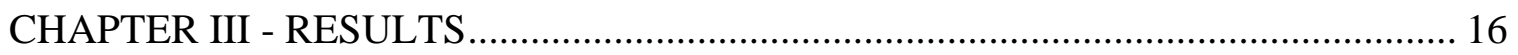

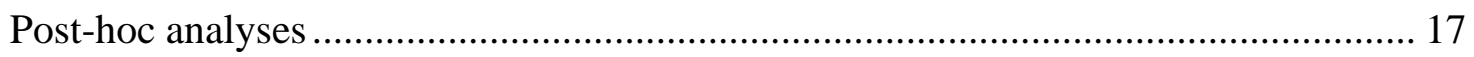

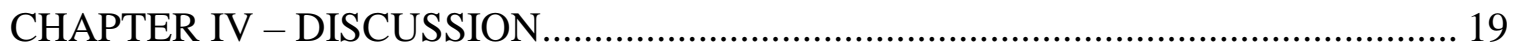

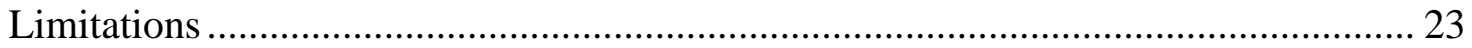

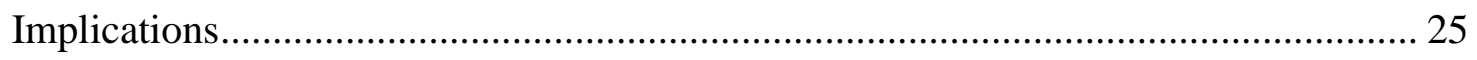

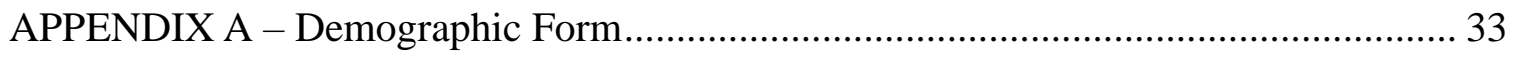

APPENDIX B - Self-identified Non-religious Label ............................................... 35

APPENDIX C - The Calling and Vocation Questionnaire .......................................... 36

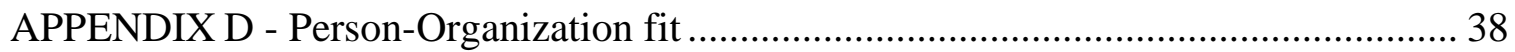

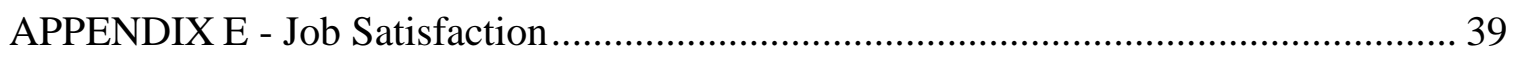

APPENDIX F - Microaggressions Against Non-religious Individuals Scale.................. 40

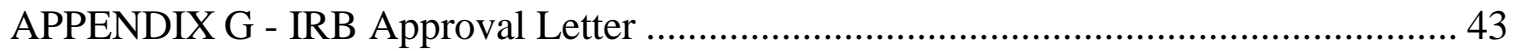

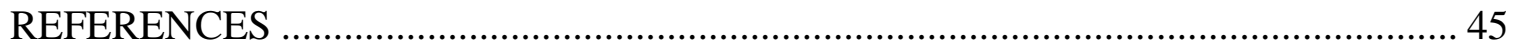




\section{LIST OF TABLES}

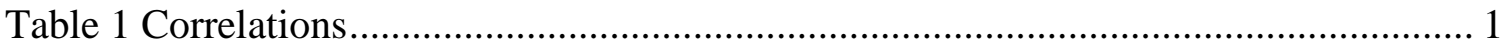




\section{LIST OF ILLUSTRATIONS}

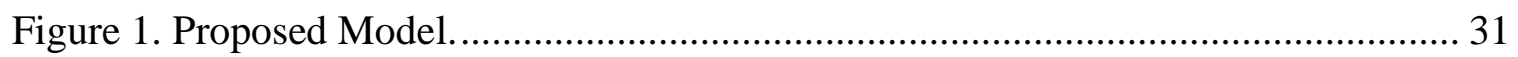

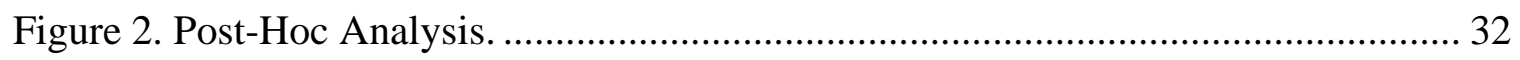




\section{LIST OF ABBREVIATIONS}

$\begin{array}{ll}P \text {-O fit } & \begin{array}{l}\text { Person-Organization fit } \\ T W A\end{array} \\ \text { Theory of Work Adjustment } \\ \text { The } & \begin{array}{l}\text { Microaggressions Against Non-religious } \\ \text { Individuals Survey }\end{array} \\ E S & \text { Calling and Vocation Questionnaire } \\ M P & \text { External Summons } \\ P M & \text { Meaning/purpose } \\ & \text { Prosocial Motivation }\end{array}$




\section{CHAPTER I - LITERATURE REVIEW}

Non-Religious employees' perceptions of microaggressions and their relationship to job satisfaction as moderated by calling

Across the literature, population growth within the nonreligious community has been noted (Cragun, Nielsen, Hammer, \& Autz, 2018; PEW Research Center for Religion and Public Life, 2014). This trend has inspired interest in understanding the implications of a non-religious identity in different contexts (Caldwell-Harris, Wilson, LoTempio, \& Beit-Hallahmi, 2011; Doane \& Elliot, 2015; Galen \& Kloet, 2011; Hayward, Krause, Ironson, Hill, \& Emmons, 2016); yet, few studies have explored the implications of this identity within the workplace. Instead, research regarding workplace religious identity focuses on non-secular experiences. For example, calling is a concept that has become popular in vocational research that focuses on the experiences of religious individuals. Previous studies on calling have examined religious characteristics of participants such as church attendance and spiritual well-being (Dik, Eldridge, Steger, \& Duffy, 2012; Hall, Burkholder, \& Sterner, 2013; Hovarth, 2015). However, results have yet to provide insight on strictly non-religious groups. The recent population growth of this minority group highlights the importance of expanding the literature involving calling and job satisfaction to include their experiences.

The current study makes important contributions to the literature. First, the examination of the effect of presence of and search for calling on job satisfaction in nonreligious groups could aid in career counseling strategies for this growing minority group. Secondly, understanding how calling might mitigate microaggressions against nonreligious groups at work could add to the body of research regarding calling and other 
minorities to identify potential mechanisms for improving the work lives of minority groups. Therefore, the aim of this study is to examine the relationships between microaggressions against non-religious individuals at work, calling, and job satisfaction.

\section{Microaggressions}

Microaggressions have been described as intentional or unintentional brief slights that can be verbal, behavioral, or environmental that demonstrate hostility toward targeted groups or individuals (Nadal, 2011; Nadal, Davidoff, Davis, Wong, Marshall, \& Mckenzie, 2015). Because of their commonplace nature, research in microaggressions often focuses on their prevalence within the workplace (Baseford, Offerman, \& Behrend, 2014; Holder, Jackson, \& Ponterotto, 2015; Nadal, Wong, Griffin, Davidoff, Sriken, 2014). Like the effects of discrimination, microaggressions can be harmful to the wellbeing and job satisfaction of the targeted individuals (Lewis, Derlega, Griffin, \& Krowinski, 2003; Nadal, Griffin, Wong, Hamit, \& Rasmus, 2014; Nadal, Wong, Griffin, Davidoff, \& Sriken, 2014; Salvatore \& Shelton, 2007). There is little research regarding workplace microaggressions against non-religious groups. The Theory of Work Adjustment, a prevalent framework for predicting individuals' job satisfaction, offers some hypotheses on how microaggressions against non-religious individuals may affect their perceptions of fit with their organization and job satisfaction.

Theory of Work Adjustment. Known as a person-environment fit theory, the Theory of Work Adjustment (TWA) describes that job satisfaction (Dawis, 2005) is a result of the fit between an individual's needs and values and those needs reinforced in the work environment. These needs and values vary across employees based on personal priorities. Reinforcement of different workers' needs is also variable across work 
environments. This fit between worker and his/her organization, described by TWA, has also been termed, person-organization fit (P-O fit). However, multiple types of fit are described across the literature that vary based on the specific aspect of the environment being compared, such as the work group (person-group fit), supervisor (person-supervisor fit) or job (person-job fit; Greguras \& Diefendorff, 2009). In particular, TWA assumes that $\mathrm{P}-\mathrm{O}$ fit is sensitive to the interaction between individual differences in values for employees and differences in values for the organization as a whole whereas other indices of fit are less sensitive to the individual differences that may be affected by microaggressions. Job satisfaction, then is how well the employee's social, personal, and environmental needs are met as predicted by P-O fit (Dawis, 2005). Thus, those who have high P-O fit are predicted to have higher job satisfaction than those with low P-O fit (Dawis, 2005). This relationship has been supported across a number of studies. A metaanalysis of the research indicates a moderate positive correlation between P-O fit and job satisfaction (e.g., $r=.45$; Kristof-Brown, Zimmerman, \& Johnson, 2005).

Discussed within the broader aspects of the TWA, P-O fit is assumed to vary widely across individuals given that values are subjective and highly variable across individual workers (Dawis, 2005; Resick, Baltes, Shantz, 2007). For example, research has found that work values, as the basis of P-O fit, are related to personality and interests (Bilsky \& Schwartz, 1994; Leuty \& Hansen, 2011) and can vary across birth cohort (Twenge, 2010). Moreover, Judge and Kristof-Brown (2004) discuss that P-O fit and personality are intertwined as individuals tend to seek out environments consistent with their personality thus resulting in higher perceptions of P-O fit. Therefore, $\mathrm{P}-\mathrm{O}$ fit can be assumed to be affected by a number of individual differences. 
Given these individual antecedents to P-O fit, such as personality and values, it is not surprising that TWA is a common framework used to study work experiences of individuals from minority groups (Lovelace \& Rosen, 1996; Lyons \& O’Brien, 2006; Lyons, et al., 2014). In a number of studies, this research has found that P-O fit is highly positively associated with supportive workplace climates for minorities while experiences of workplace discrimination or unwelcoming climates relates to reduced perceptions of P-O fit and lowered job satisfaction for minorities (Lyons et al., 2014; Martinez et al., 2017; Velez \& Moraldi, 2012). Previous research comparing racial minorities' perceptions of $\mathrm{P}-\mathrm{O}$ fit with those from majority racial groups perceptions revealed that perceptions of fit vary based on group membership (Lovelace \& Rosen, 1996). In economically distressed African Americans, increased P-O fit was associated with increased positive perceptions of racial climate at the workplace and P-O fit was significantly positively related to an increase in job satisfaction (Lyons et al., 2014). Additionally, there have been several studies conducted with members of the LGBT community (Allan, Tebbe, Duffy, \& Autin, 2014; Martinez, Sawyer, Thoroughgood, Ruggs, \& Smith, 2017; Sears \& Mallory, 2011; Velez \& Moradi, 2012), which may provide hypotheses about the experiences of non-religious individuals as both groups have the ability to hide their religious and sexual identities while at work. Similar to other minorities, research in workplace microaggressions or discrimination against LGBT individuals has revealed a distinct negative relationship between P-O fit and microaggressions such that, when LGBT values (i.e., supportive work climates) are not met, perceptions of P-O fit decrease (Lyons, et al., 2014; Velez \& Moradi, 2012). For instance, among LGB individuals, high workplace heterosexist discrimination related to 
low P-O fit, which related to lowered job satisfaction while climates supportive of LGB individuals, lead to higher perceptions of P-O fit and higher reported job satisfaction (Velez \& Moraldi, 2012). In a sample of transgender individuals, co-worker acceptance of chosen gender identity mediated negative relationships between extent of gender transition and job satisfaction, P-O fit, and lower perceived discrimination (Martinez et al., 2016).

This research illustrates a strong relationship between $\mathrm{P}-\mathrm{O}$ fit and job satisfaction reflecting the relationship described by the TWA in minority populations. However, P-O fit can be negatively affected by the microaggressions commonly experienced by these populations in the workplace. When individuals experience microaggressions, their social and personal needs of acceptance are not being reinforced by the environment, thus affecting their P-O fit and job satisfaction. Thus, consistent with TWA, it can be expected that microaggressions against non-religious individuals at work would negatively relate to job satisfaction, as well as this relationship being mediated by P-O fit. Yet, minority groups may still experience high levels of job satisfaction due to factors other than P-O fit, such as calling, which relate to job satisfaction. Several studies have found that calling and job satisfaction are highly positively correlated (Allan, Tebbe, Duffy, \& Autin, 2015; Duffy, Blake, Allan, Autin, \& Douglas, 2014; Duffy, Bott, Allan, Torrey, \& Dik, 2012; Neubert \& Halbesleben, 2015).

\section{Calling}

The concept of calling has become a popular topic in vocational research in recent years. Calling is generally characterized by an individual's drive to connect their work to meaningfulness derived from external sources (Dik \& Duffy, 2009). A more detailed 
conceptualization of calling by Dik and Duffy (2009) proposes that calling is defined by three components: external summons, meaning/purpose, and prosocial motivation. External summons (ES) occurs when individuals feel compelled by something greater than themselves to pursue a specific career. When an individuals' career decision was meaning/purpose (MP) driven, they chose a career that aligned with their sense of purpose in life. Prosocial motivation-based calling (PM) occurs when an individual feels an obligation to help others in their career. (Dik \& Duffy, 2009; Duffy \& Dik; 2013; Dik, Steger, Eldridge, \& Duffy, 2012).

Investigation into the contribution of having or striving for a calling has suggested that calling may serve to enhance both one's career and individual well-being. This relationship has been demonstrated across multiple samples in the literature described by Duffy and Dik (2013). Research with student populations has revealed a positive correlation between calling and life meaning/satisfaction (Duffy, Allan, \& Bott, 2012; Duffy \& Sedlacek, 2010; Steger, Pickering, Shin, \& Dik, 2010). Research with adult populations has yielded similar results but found stronger relationships between calling and life satisfaction than have been found in college student samples (Davidson \& Caddell, 1994; Wrzesniewski, McCauley, Rozin, \& Schwartz, 1997). Work variables positively associated with calling include organizational and career commitment, work engagement, and person-job fit (Duffy \& Dik, 2013; Duffy, Allan, \& Dik, 2011; Hirschi, 2012). In sum, these findings demonstrate potentially positive effects in both work and life of having a calling.

Originally, the concept of calling had a religious connotation. The historic definition assigned spiritual significance to occupations held by those who felt 'called' 
specifically by a higher power (Dik \& Duffy, 2009). Modern definitions place much more focus on the needs and values of the individual; however, much of calling research continues to explore the importance of religion or spirituality in career decision-making (Dik \& Duffy, 2009; Dik et al., 2012; Duffy, Allan, \& Bott, 2011; Hall, Burkholder, \& Sterner, 2014; Hovarth, 2015). Studies examining calling have compared groups of those with high religious importance to those with low religious importance and usually find that calling is significantly higher for those with high religious importance. For example, it was found that those who attended religious services on a regular basis had higher levels of calling than those with low attendance (Dik et al., 2014). Further research indicated that this was also true for the specific facets of calling (ES, MP, PM; Ponton, Brown, McDonnell, Clark, \& Pepe, 2014).

More detailed explorations of religiousness and calling have illuminated a complicated relationship with attitudes and behavioral outcomes. Despite having higher levels of calling, those with high religiousness have less job involvement and work fewer hours (Hovarth, 2015). When comparing undergraduate students with high and low religiousness, it was found that religiousness did not moderate an established relationship between calling and life satisfaction (Duffy, Allan, \& Bott, 2011). Among graduate students in counseling psychology, when existential and spiritual well-being was compared, having high existential well-being was a better predictor of having a sense of calling than spiritual well-being (Hall, Burkholder, \& Sterner, 2014). These findings indicate that those with high levels of religiousness generally report having a calling more so than those with low levels of religiousness, and higher calling correlates with positive outcomes regarding job satisfaction. Calling may have similar benefits for those 
with low levels of religiousness; however, there has been limited research conducted to examine the effect of having a calling among individuals identifying as non-religious specifically.

\section{The Current Study and Hypotheses}

In sum, the TWA posits there is a positive relationship between P-O fit and job satisfaction for employees (Dawis, 2007). Yet, research on microaggressions, has found that microaggressions have a significantly negative relationship to P-O fit leading to lowered job satisfaction within minority groups (Lyons et al., 2014; Velez \& Moradi, 2012). Given that non-religious individuals experience microaggressions similar to other minority groups (Doane \& Elliot, 2015; Hunter, 2001; Strosser, Jonason, Lawson, Reid, \& Vittum-Jones, 2016), it is likely that a similar relationship between microaggressions and P-O fit exists for these individuals, such that it can be expected that increased microaggressions should be related to decreased P-O fit and lowered job satisfaction. Moreover, calling appears to be positively related to P-O fit and job satisfaction (Duffy \& Dik, 2013; Duffy, Allan, \& Dik, 2011; Hirschi, 2012). Studies comparing religious and non-religious individuals' calling have yielded mixed results and very few have examined non-religious individuals alone (Dik \& Duffy, 2009; Dik et al., 2012; Duffy, Allan, \& Bott, 2011; Hall, Burkholder, \& Sterner, 2014; Hovarth, 2015). Exploring interactions between calling and microaggressions and their relation to job satisfaction for non-religious workers will simultaneously expand research on calling and those identifying as non-religious. Furthermore, results of this study may help inform vocational counseling for the growing number of non-religious individuals. 
Taking previous literature into consideration, the following predictions about the relations between microaggressions, $\mathrm{P}-\mathrm{O}$ fit, calling, and job satisfaction were made as depicted in Figure 1.

1. Microaggressions and P-O fit will be significant predictors of job satisfaction.

a. Higher microaggressions will predict decreased job satisfaction

b. Higher P-O fit will predict increased job satisfaction

2. P-O fit will mediate the relationship between microaggressions and job satisfaction.

3. Calling will be positively correlated with P-O fit and with job satisfaction.

4. Calling will moderate the relationship between microaggressions and P-O fit in the workplace.

a. Higher presence of a calling will decrease strength of the relationship between microaggressions and $\mathrm{P}-\mathrm{O}$ fit. 


\section{CHAPTER II - METHODS \\ Participants}

Following data cleaning (described below) a total of 296 valid cases were identified. Participants' age ranged from 18 to 67 years $(\mathrm{M}=33.97, \mathrm{SD}=9.23)$ with $49.8 \%$ identifying as male and $50.2 \%$ identifying as female. Approximately $84.4 \%$ of participants identified as White/Caucasian, 5.4\% Hispanic/Latino, 4.4\%

Multicultural/Multiracial, 2\% Other, 1.7\% Asian American, 1\% Black/African American, and $.7 \%$ Pacific Islander. Of respondents, $19.2 \%$ reported residing outside the US. Most respondents (69.4\%) had received a bachelor's degree or above. The self-reported religious identity questionnaire indicated that $71 \%$ of individuals identified at Atheist, 17.8\% identified as Agnostic, and 11.1\% identified as spiritual non-religious with most individuals supporting the accuracy of these labels with their identity $(\mathrm{M}=8.8, \mathrm{SD}=$ 1.78). Most individuals (59.6\%) indicated that they never participate in religious activities and $88.9 \%$ of individuals participate less than one time per month. Most participants $(42.4 \%)$ indicated that only one or two of their coworkers knew about their non-religious identity.

\section{Measures}

Self-identified non-religious label. Similar to the approach taken by other researchers (Galen \& Kloet, 2011; Hayward, Krause, Ironson, Hill, \& Emmons, 2016; Keller, Bullik, Klein, \& Swanson, 2018; Sherkat, 2008), a categorical question designed to assess the participant's non-religious orientation was used. Options provided for this question included Atheist, Agnostic, and Spiritual non-religious (Appendix B). 
Calling Vocation Questionnaire (CVQ). The Calling Vocation Questionnaire (CVQ) is a 24-item likert-style questionnaire developed by Dik, Eldridge, Steger, and Duffy (2012) for the purpose of measuring presence (i.e., currently working within the field to which they have been 'called') of and search for calling (i.e., actively seeking or pursuing a field or career to which they will feel 'called'). These domains are further subdivided into three subcategories defined by the participant's origin of his/her sense of calling. These include transcendent summons (TS; feeling 'called' by something greater than oneself), prosocial motivation (PM; feeling an obligation to those around them), and purposeful work (PW; providing meaning to the work role; Dik et al., 2012). Participants were asked to either agree or disagree with the statements in the measure on a 4-point scale $(1=$ Not at all true of me, $4=$ Absolutely true of me). Sample items include "I see my career as a path to purpose in life" and "I am trying to build a career that benefits society" (Appendix C; Dik et al., 2012). Since its development, the measure has been reliably used in previous studies to measure calling (Duffy, Allan, \& Bott, 2012; Hovarth, 2015; Ponton, Brown, McDonnell, Clark, \& Pepe, 2014). Internal consistencies for CVQ subscales are high, ranging from .83 to .93 in adult samples (Dik et al., 2012). The Cronbach's alphas among the three CVQ subscales was acceptable for the current study $(\mathrm{PW}=.87, \mathrm{PM}=$ $.84, \mathrm{TS}=.65$ ), and are listed in Table 1 with the reliabilities for each measure for this sample.

Microaggressions Against Non-religious Individuals Survey (MANRIS). The Microaggressions Against Non-religious Individuals Survey (MANRIS) was developed by Cheng, Pagano, and Shariff (2018) for the purpose of measuring the different types of microaggressions experienced by non-religious individuals. The measure is separated into 
five categories each containing items that pertain to a different common microaggressions experienced by non-religious individuals. These categories are assumptions of inferiority, denial of religious prejudice, assumptions of religiosity, endorsing non-religious stereotypes, and pathology of non-religious identity. The measure has 31 items answered using a 5 -point scale $(1=$ Never, $5=10$ or more times $)$ to indicate the frequency a specific microaggression has occurred. Sample items include "Others have assumed I am untrustworthy because of my lack of religion" and "Others have assumed that all people in my non-religious group are all the same" (Appendix D; Cheng et al., 2018). Due to the recent publication of this measure, research using the MANRIS is limited; however, items were developed by consulting with those with expertise on microaggressions. Additionally, there is evidence for convergent validity between the MANRIS and other measures of non-religious discrimination (Cheng et al., 2018). Internal consistency estimates have been high, including a Cronbach's alpha of .97 in adult populations (Cheng et al., 2018). Cronbach's alpha for the current sample was high $(\alpha=.98)$.

Job Satisfaction. Job satisfaction was assessed using five items taken from a larger measure of job satisfaction (Brayfield \& Rothe, 1951). This shortened measure has been used in several studies examining job satisfaction in recent years and has shown evidence for strong reliability and validity (Duffy, Bott, Torrey, Allan, \& Dik, 2012; Duffy, Bott, Torrey, \& Webster, 2013; Judge, Locke, Durhanm, \& Kluger, 1998). The measure requires participants to rate their agreement with each statement on a 10-point Likert scale $(1=$ strongly disagree, $10=$ strongly agree $)$. Sample items include, "each day of work seems like it will never end" and "I find real enjoyment in my work" (Judge, et al., 
1998). Validation studies on this measure have documented strong internal consistency ( $\alpha$ $=.88$ ) in working adult samples (Duffy et al., 2012; Judge, et al., 1998), as was found in the current sample $(\alpha=.91)$.

Person-Organization Fit ( $P-O$ fit). P-O fit was measured using Saks and Ashforth's (1997) measure of P-O fit. This subscale has been used in previous research examining perceptions of P-O fit (Resick, Baltes, \& Walker Shantz, 2007; Velez \& Moraldi, 2012). The measure requires participants to rate their agreement with the provided statements using a 5 -point Likert scale $(1=$ to a very little extend, $5=$ to very large extent $)$. Sample items include "to what extent are the values of the organization similar to your own values" and "to what extent does the organization fulfill your needs" (Appendix F; Saks $\&$ Ashforth, 1997). This measure has demonstrated strong internal consistency $(\alpha=.94)$ across previous studies with employed adults (Resick et al., 2007; Velez \& Moraldi, 2012). Evidence of construct validity has been demonstrated by confirmatory factor analysis where items highly loaded to the P-O fit scale. Convergent and discriminant validity were supported given correlations between the P-O fit scale and a one-item assessment of P-O fit $(r=.81)$ and a measure of Person-job fit ( $r=.52$; Saks \& Ashforth, 1997). The Cronbach's alpha for the current sample was .92 .

\section{Procedures}

Because this study focused specifically on non-religious individuals, participants were gathered from popular non-religious internet communities (i.e Facebook and Reddit). After IRB approval for this study was obtained, a link to the questionnaires, hosted on Qualtrics, was posted to a thread requesting participants for a research study interested in understanding experiences of non-religious individuals in the workplace. 
Participants were required to identify as non-religious, be currently employed, and be above 18 years of age to be included in this study. Once consent was given and participants indicated that they meet the inclusion criteria, participants were asked to provide demographic information including age, sex, annual income, education, marital status, and employment status including hours worked, occupation, and tenure in addition to the information that was gathered from the questionnaires (Appendix A - E) which were presented in a randomized order. However, in order to control for any potential distress caused by recalling microaggressions affecting responses to other items (e.g., PO fit, job satisfaction), participants were given the MANRIS last (Appendix F). Following the completion of these questionnaires, participants were thanked for their time and participation in the study.

Data cleaning was performed to remove all invalid and incomplete cases from the dataset prior to analyses. All cases that responded incorrectly to one or more of the three imbedded validity checks were removed from the study $(n=29)$. Cases $(n=85)$ that did not have all essential assessments (demographics, job sat, P-O fit, CVQ, and MANRIS) completed or were missing greater than $25 \%$ of item responses were removed from the data. Four missing data points across the measures were replaced by imputation using linear trend at point. Following this, appropriate items were reverse-scored and total scores for each measure were calculated. All cases with religious-identifying individuals were filtered from the data $(\mathrm{n}=17)$.

A multiple regression analysis was conducted to test assumptions and diagnostics of the data. Microaggressions and P-O fit variables were centered prior to this analysis. There was no violation of multicollinearity. There was no violation of linearity or 
homoscedasticity and skewness (-1.47) and kurtosis (1.22) were acceptable indicating no violation of normality of errors. Following this, data were examined to reveal any possible outliers. This process revealed one outlier which was removed prior to the multiple regression analysis. 


\section{CHAPTER III - RESULTS}

Analyses for all hypotheses were analyzed using IBM SPSS statistics (version 25; IBM Corp., 2017) and Andrew Hayes' (2003) PROCESS (v3.3) macro for SPSS. The first hypothesis was tested using a multiple regression analysis. The first hypothesis predicted that microaggressions would be significantly negatively related to job satisfaction and that $\mathrm{P}-\mathrm{O}$ fit would be significantly positively related to job satisfaction. The results of this analysis supported these predictions. P-O fit and microaggressions together accounted for $46.3 \%$ of the variance in job satisfaction $[F(2,293)=126.17, p<$ $.001]$. Results supported that microaggressions $(B=-.036)$ were negatively related to job satisfaction, while P-O fit $(B=7.12)$ was positively related.

The second hypothesis was tested using Andrew Hayes' (2003) PROCESS v(3.3) macro for SPSS. Hypothesis 2 predicted that P-O fit would mediate the relationship between microaggressions and job satisfaction. The analysis did not support this hypothesis. Specifically, results indicated that microaggressions were a significant predictor for job satisfaction $[b=-.0514), t(294)=-2.37, p<.05]$, but not a significant predictor of P-O fit $[b=-.002, t(294)=-1.025, p>.05]$. Without a significant relationship between microaggressions and P-O fit, no further examination of possible mediation was conducted.

The third hypothesis predicted calling would be significantly correlated with P-O fit and job satisfaction. It was found that presence of calling was significantly related to both P-O fit $(r=.220)$ and job satisfaction $(r=.199)$. Further analysis on the components of calling (transcendent summons, prosocial motivation, purposeful work), found P-O fit 
and job satisfaction were significantly related to prosocial motivation $(r=.165, r=.168$, respectively) and purposeful work $(r=.231, r=.190)$ but not for transcendent summons $(r=.086, r=.106)$. See Table 1 for all correlations.

The fourth hypothesis predicted that presence of calling would moderate the relationship between microaggressions and $\mathrm{P}-\mathrm{O}$ fit. A centered variable was created for presence of calling and an interaction term was created using this centered variable and the centered variable for microaggressions. The centered variables were entered into a regression on the first step, and the interaction term was entered on the second. Results revealed that the proposed moderation model was not significant. Specifically, while microaggressions $(B=-.003)$ and presence of calling $(B=.03)$ were significant predictors of job satisfaction, $\left[R^{2}=.047, F(2,293)=7.204, p<.001\right]$, the interaction term was not a significant predictor $\left[\Delta R^{2}=.001, B=.00, t(3,292)=.402, \mathrm{~ns}\right]$.

\section{Post-hoc analyses}

While calling did not moderate the relationship between MANRIS scores and P-O fit, a post-hoc analysis was performed in order to test presence of calling as a moderator for the relationship between microaggressions and job satisfaction. Results revealed that this moderation was significant. Specifically, microaggressions $(B=-.06)$ and presence of calling $(B=.27)$ were significant predictors of job satisfaction $\left[R^{2}=.06, F(2,293)=\right.$ $9.311, p<.001]$. Additionally, the interaction term was a significant predictor for job satisfaction $\left[\Delta R^{2}=.02, B=.01, \Delta F(1,292)=6.45, p<.05\right]$. The interaction was probed to identify significant slopes (Figure 2). Results revealed that microaggressions were significantly related to job satisfaction when non-religious individuals reported low calling (-1 SD) and average calling. However, the relationship between microaggressions 
and job satisfaction was not significant at high levels of calling (+ $1 S D)$. In other words, when calling was high, the negative association between microaggressions and job satisfaction was not significant. 


\section{CHAPTER IV - DISCUSSION}

The purpose of this study was to examine the relationship between workplace microaggressions and career outcomes for non-religious individuals. Similar to previous research, and consistent with the Theory of Work Adjustment, results demonstrated that microaggressions and $\mathrm{P}-\mathrm{O}$ fit were significant predictors of job satisfaction; however, there was not a significant relationship between microaggressions and $\mathrm{P}-\mathrm{O}$ fit. Thus, $\mathrm{P}-\mathrm{O}$ fit was not examined as a mediator of the relationship between microaggressions and job satisfaction, as hypothesized. Additionally, results revealed that presence of calling did not change the non-significant relationship between P-O fit and microaggressions; however, post hoc analyses indicated that presence of calling significantly moderated the relationship between microaggressions and job satisfaction. Correlation analyses revealed significant relationships between some components of calling (e.g. prosocial motivation and purposeful work) but not others (e.g. transcendent summons; Table 1).

Results of the first hypothesis reflect what has been found in previous literature, such that individuals experiencing more microaggressions are more likely to report lower job satisfaction (Lewis et al., 2003; Nadal, Griffith, et al., 2014; Nadal, Wong, et al., 2014; Salvatore \& Shelton, 2007) and those with high P-O fit are more likely to have high job satisfaction (Dawis, 2005; Kristof-Brown et al., 2005). Thus, these data extend this literature to include these relationships regarding microaggressions pertaining to one's non-religious identity.

However, the results regarding the relationship between $\mathrm{P}-\mathrm{O}$ fit and microaggressions is inconsistent with previous research on other marginalized 
populations. Previous examinations of microaggressions have indicated a relationship between microaggressions and fit such that high self-reported microaggressions predict low self-reported P-O fit in minority groups (Lyons, et al., 2014; Velez \& Moradi, 2012). These findings may be explained by the difference in populations. Lyons et al. (2014) examined workplace microaggressions amongst an African American population and Velez and Moradi's (2012) research examined the workplace experiences of LGB individuals, both finding that microaggressions toward these identities related to reduced perceptions of P-O fit. It was hypothesized that these findings would be reflected in research with non-religious individuals; however, results indicated that microaggressions did not predict P-O fit in this sample. This difference indicates a discrepancy between LGB and African American populations and non-religious populations' interpretation of microaggressions. It may be that these identities related to ethnicity or sexual orientation are more closely held than a non-religious identity, and more apt to affect other attitudes when denigrated. Alternatively, it may be that fit with the organization is less affected by non-religious microaggressions, as fit with one's organization overall is not the only aspect of the work environment that can be affected by microaggressions. Person-group fit and person-job fit (Greguras \& Diefendorff, 2009) are additional aspects of the work environment that were not explored by the current research. Unlike P-O fit, these narrow aspects of fit may be affected by microaggressions in non-religious individuals. For nonreligious groups, increased microaggressions may be interpreted as being a product of the values of those with whom they work (e.g. person-group and person-job fit) as opposed to the organization as a whole. Meanwhile, other minority groups may view microaggressions as being indicative of the values of the organization as a whole (e.g. P- 
$\mathrm{O}$ fit). Research examining the relationship between these narrower types of fit and microaggressions in minority groups is lacking; however, identifying these relationships may help researchers understand differences between minority groups' interpretation of microaggressions in the workplace.

The third hypothesis predicted that calling would be positively correlated with job satisfaction and with P-O fit. In line with previous research, results revealed that calling is significantly related to P-O fit and job satisfaction (Duffy \& Dik, 2013; Duffy, Allan, \& Dik, 2011; Hirschi, 2012). However, additional analyses revealed that not all components of calling (transcendent summons, prosocial motivation, purposeful work) are significant predictors of job satisfaction or P-O fit for non-religious individuals. Specifically, transcendent summons is not significantly related to job satisfaction or P-O fit while purposeful work and prosocial motivation are significantly related. This finding may be due to the non-religious identity of the sample. The majority of individuals in this sample do not believe in God or gods, a concept that is evoked with the questions associated with transcendent summons on the CVQ. For example, "I was drawn by something beyond myself to pursue my current line of work" may be interpreted by this specific group as having to do with God or gods which may make them less likely to endorse this type of question. Thus, while calling as a whole is significantly related to job satisfaction and P-O fit for non-religious groups, transcendent summons is not a necessary component. Future research could benefit from further exploration of transcendent summons' relationship with other work outcomes in non-religious groups to identify the utility of the construct when working with non-religious individuals. 
Finally, it was predicted that calling would moderate the relationship between microaggressions and $\mathrm{P}-\mathrm{O}$ fit such that those with high calling would express higher levels of P-O fit despite the level of perceived microaggressions. In this model, calling was a significant predictor of $\mathrm{P}-\mathrm{O}$ fit but microaggressions were not. These findings indicate that the presence of calling has no effect on the relationship between microaggressions and P-O fit. Comparing this finding with similar models using other indices of person-environment fit (e.g. person-group and person-job fit) may explain the insignificant moderating effect. For example, when using these other types of fit, a significant relationship between fit and microaggressions may be found and significantly moderated by calling. Similar to the discussion of the third hypothesis, non-religious individuals may be more likely to endorse $\mathrm{P}-\mathrm{O}$ fit despite microaggressions because they are more likely to attribute these actions to the individuals with whom they work or their work values rather than the organization as a whole. Person-group and person-job fit capture these aspects of work. Thus, unlike P-O fit, person-group or person-job fit may be more sensitive to the effect of microaggressions because they are rooted in one's perceptions of their fit with their colleagues' values or the specific job which may be more sensitive to the effects of microaggressions than broader perceptions of fitting with one's organization. Thus, examining more narrow aspects of fit may have changed the results of this moderation analysis. Further, significant relationships between microaggressions and work-related outcomes should be examined using each component of calling, such as search for calling and presence of calling or transcendent summons and prosocial motivation. Comparing the moderating effect of the different types of 
calling may offer further explanation for these findings and for the utility of calling as a whole for non-religious minority groups.

Given the lack of research on calling in non-religious samples, post-hoc analyses were conducted to explore the moderating effect of calling on the relationship between microaggressions and job satisfaction. Results revealed that calling and microaggressions as well as the interaction term were all significant predictors of job satisfaction. This indicates that calling has a significant effect on the relationship between microaggressions and job satisfaction such that, when experiencing high levels of microaggressions, those with low and moderate calling have significantly lower job satisfaction than those with high calling. In other words, not only is calling present in non-religious individuals, but its presence buffers the negative effect of microaggressions on job satisfaction. Previous research that has examined the connection between calling and work variables have found similar trends. For example, Creed, Rogers, Praskova, and Searle (2014) found that calling had a protective effect for medical students dealing with high levels of stress such that those reporting a calling were less likely to experience burnout despite high academic demands. They attributed this finding to calling's relationship with well-being and concluded that this increase in well-being may help individuals navigate the daily stressors associated with medical school (Creed et al., 2014). For non-religious individuals who experience moderate and high calling, microaggressions are less likely to decrease the satisfaction they derive from their work.

\section{Limitations}

The current research and implications therein should be interpreted while acknowledging limitations associated with data collection procedures. Participants used 
for this study were recruited from online forums. While the specific forums used to gather participants were created specifically for non-religious individuals, they are open to anyone. This means that there is a possibility that those who took the survey may not have been honest about their identity or experiences. Participant feedback indicated that, though they may experience microaggressions from their family or loved ones on a regular basis, they rarely experience these types interactions with their coworkers. Many respondents posted comments to the thread beneath the survey explaining that the experience of microaggressions within the workplace based on religious identity is rare because religion is not a commonly appropriate workplace topic. Based on this qualitative information, the measure of microaggressions may be susceptible to floor effects and results of this measure should be interpreted with caution. Additionally, the goal of this research was to examine the effect of marginalized groups with non-religious identities including atheists, agnostics, and spiritual non-religious; however, other niche identities exist (i.e. Satanists, Pastafarians, Humanists, etc.). These groups were solicited for this study, but specific religious demographic categories were not provided. Research examining differences between specific groups within the non-religious identity such as these is limited. Future research with non-religious populations may benefit from exploring a wider variety of secular identities. Additionally, individuals who identify as religious but are non-Christian often face microaggressions due to their status as a religious minority (Nadal, et al., 2015; Nadal, Griffin, Hamit, Leon, Tobio, \& Rivera, 2012; Nadal, Issa, Griffin, Hamit, \& Lyons, 2010). The present research focused on identifying the effect of workplace microaggressions within non-religious individuals; 
however, future research should examine the effect of microaggressions and calling with non-Christian religious minorities.

\section{Implications}

Due to the recent growth of the non-religious community, it has become more important to understand this population, yet few studies have been designed to examine and understand the experiences of this group especially within the workplace. Previous studies have examined the effect of calling in employees and student populations (Dik et al., 2012; Duffy, Allan, \& Bott, 2011; Hall, Burkholder, \& Sterner, 2014; Hovarth, 2015) yet very little research has examined the effects of calling in minority groups. Allan et al. (2014) examined variables similar to those used in the current study with a population of LGB individuals and found that calling and workplace climate were significant predictors of job satisfaction; however, the researchers did not examine calling as a moderator. Future research may benefit from testing if calling may perform as a protective factor against microaggressions within other minority groups at work.

Additionally, while previous research on calling has acknowledged the presence of calling within non-religious individuals (Dik et al., 2014; Duffy, Allan, \& Bott, 2011), no previous research has explored the possibility of focusing on calling in career interventions to assist non-religious clients with work-related concerns. The results of this study indicate that increasing calling may have potential as a target for intervention for buffering the negative effects of microaggressions toward non-religious individuals within the workplace. For example, implementing efforts to increase calling (i.e. assessing the importance of transcendent summons, connecting life meaning and work meaning, understanding social implications of current work-environment), or helping 
find and live out their calling in their work, may be a useful tool for helping diverse individuals overcome microaggressions and negative work environments, and a number of authors have provided suggestions on how to do so (Dik, Duffy, \& Eldridge, 2009; Dik, Reed, Shimizu, Marsh, \& Morse, 2019). Yet, very little research to date has examined empirical support for career interventions targeting calling, but what is available suggests it is effective (Dik \& Steger, 2008). Future research examining the effect of calling within other minority groups and within more niche non-religious groups will be necessary before implementation of calling as an intervention for minority individuals is recommended.

Taking the established growth of the non-religious populations into consideration, counselors can expect to be exposed to more clients identifying as non-religious in the future. Because of this, it follows that counselors will need tools appropriate for serving these clients' needs. According to the findings of this research, calling and measurements of fit may worthwhile constructs to assess in this specific population. Specifically, counselors with non-religious clients may consider addressing issues of calling to mitigate the effect of microaggressions in the workplace. This may include using the CVQ to determine if there is a presence or search for calling and identifying which specific type of calling may be useful when doing career counseling with non-religious individuals or having more intentional conversations about calling with this clientele. Further, counselors who choose to use the CVQ or discuss the prevalence of calling with the non-religious clients may find it beneficial to focus on the meaning/purpose and prosocial motivation components of calling during the intervention as these are more relevant to this population than the transcendent summons component. Additionally, the 
results of this study indicate that perception of $\mathrm{P}-\mathrm{O}$ fit within the workplace is predictive of job satisfaction making it another possibly useful tool when working with nonreligious clients. In sum, future counselors working with non-religious clients may find that discussing calling and P-O fit may be an effective way to improve satisfaction at the workplace. 
Table 1

\section{Correlations}

\begin{tabular}{|c|c|c|c|c|c|c|c|}
\hline Variables & 1 & 2 & 3 & 4 & 5 & 6 & 7 \\
\hline 1. CVQ-TS & .646 & & & & & & \\
\hline 2. CVQ-PW & $.536 * *$ & .866 & & & & & \\
\hline 3. CVQ-PM & $.364 * *$ & $.625^{* *}$ & .840 & & & & \\
\hline 4. CVQ total & $.718 * *$ & $.893 * *$ & $.840 * *$ & .878 & & & \\
\hline 5. P-O fit & .139 & $.199 * *$ & $.178^{* *}$ & $.200 * *$ & .917 & & \\
\hline 6. Job satisfaction & .086 & $.230 * *$ & $.163 * *$ & $.202 * *$ & $.663^{*}$ & .912 & \\
\hline 7. MANRIS & .006 & .002 & $.119 *$ & .056 & -.159 & -.056 & .978 \\
\hline Mean & 5.82 & 8.02 & 9.94 & 23.78 & 3.14 & 32.94 & 54.88 \\
\hline $\begin{array}{l}\text { SD } \\
\text { Note: ** Correlatic } \\
\text { and Vocation Ques } \\
\text { Purposeful work, } \\
\text { Organization fit qu }\end{array}$ & $\begin{array}{l}2.38 \\
.01 \text { level } \\
\text { Transcend } \\
\text { Vocation } \\
=\text { Microag. }\end{array}$ & $\begin{array}{l}3.32 \\
\text { tailed). Alp } \\
\text { tt Summon } \\
\text { destionnair } \\
\text { essions Ag }\end{array}$ & $\begin{array}{l}3.35 \\
\text { this samp } \\
\text {-PW = Ca } \\
\text { ence of } \mathrm{Pr} \\
\text { on-religiol }\end{array}$ & $\begin{array}{l}7.49 \\
\text { are listed in } \\
\text { ig and Voce } \\
\text { cial Motiva } \\
\text { ndividuals }\end{array}$ & $\begin{array}{l}\quad .97 \\
\text { he diagor } \\
\text { ion Ques } \\
\text { ion, P-O } \\
\text { cale }\end{array}$ & $\begin{array}{l}10.47 \\
\text { 1. CVQ- } \\
\text { onnaire - } \\
t=\text { Perso }\end{array}$ & $\begin{aligned} & 27.96 \\
&= \text { Calling } \\
& \text { esence of }\end{aligned}$ \\
\hline
\end{tabular}




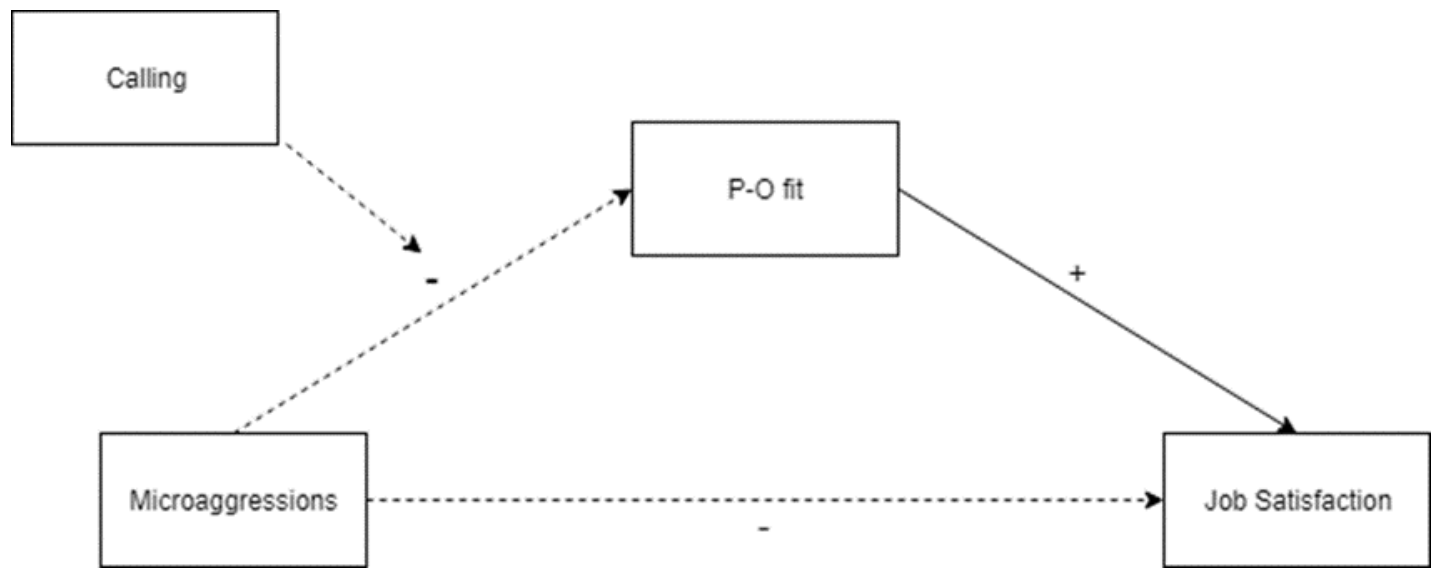

Figure 1. Proposed Model.

Note: + denotes hypothesized positive relationship, - denotes hypothesized negative relationship. 


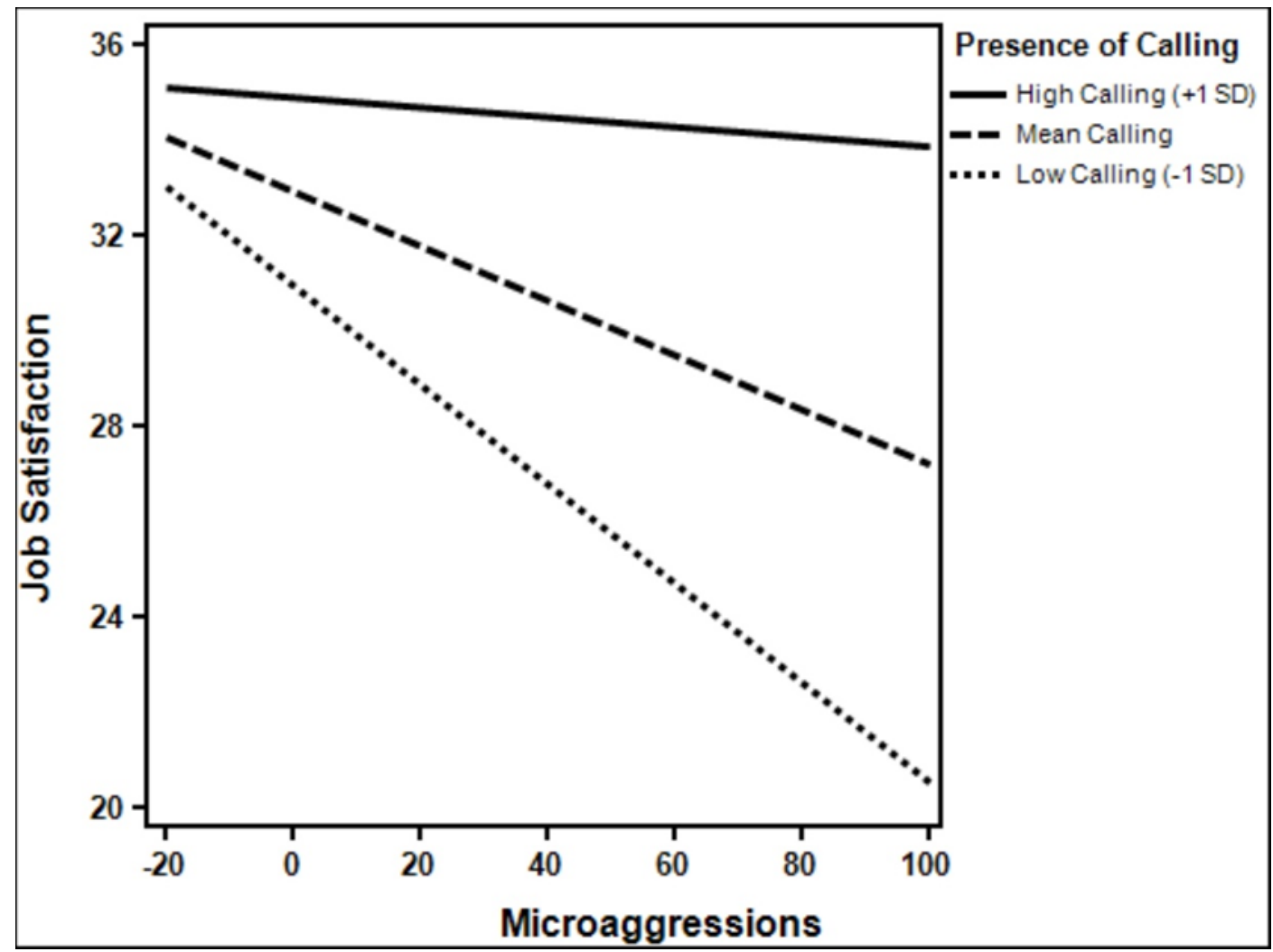

Figure 2. Post-Hoc Analysis. 


\section{APPENDIX A - Demographic Form}

\section{Demographic Form}

Please provide the following information about yourself and your household.

1. Please provide your age: years

2. What is your Date of Birth: (Month, day, year)

3. Sex: O Female

O Male

4. What is your Race/Ethnicity?

- Alaskan Native

- Black or African American

- Native Hawaiian

- American Indian

- Hispanic/Latino

- Pacific Islander

- Asian American

- White or Caucasian (non-Hispanic)

- Multicultural/Multiracial

5. What is your current relationship status?

- Single/Never married

- In a committed relationship

- In a committed relationship AND living together

- Engaged/married/partnered

○ Divorced/separated

○ Widowed

6. In what state do you live?

7. What is the highest level of education you have completed?

○ Some High School

- High School Diploma

○ Some College

- Associate's Degree

- Vocational Technology Certificate

- Bachelor's Degree

- Master's Degree

- Doctoral Degree

- Professional Degree

o other

8. Please provide the following information for the primary job you currently have.

9. How long have you been employed in this job? years, months

10. How many hours per week, on average, do you work at this job? hours

11. Are you considered part-time or full-time at this job?

12. Which of the following best describes your current (main) occupational category:

$\circ$ agriculture, food and natural resources 


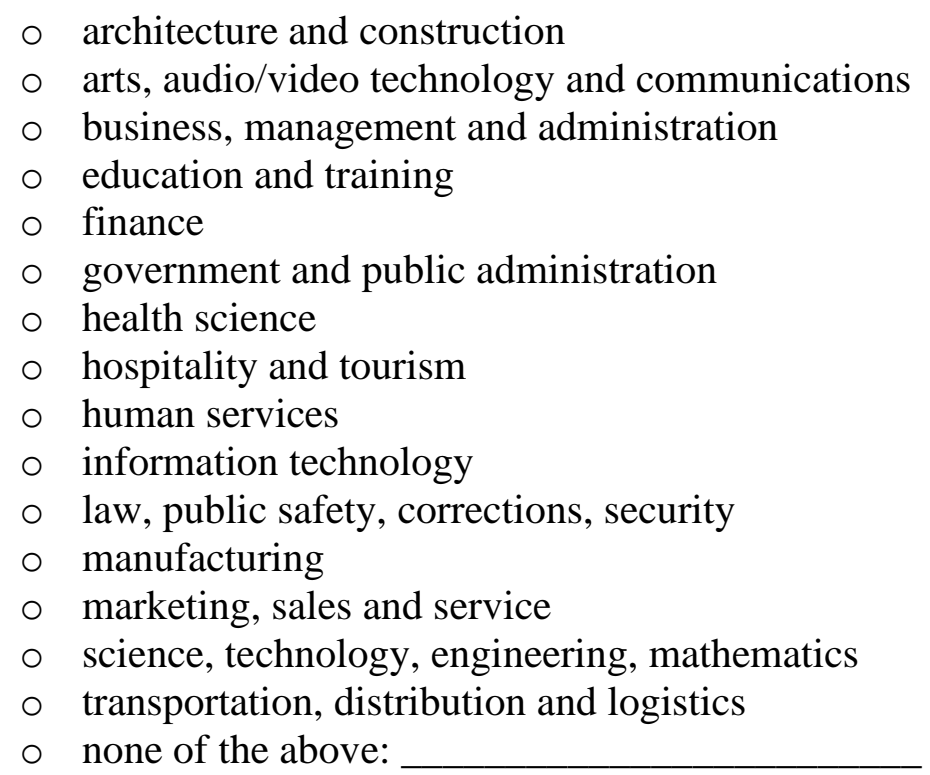

13. What is your total household gross annual income?

14. Are you enrolled in school currently?

○ Yes

○ No 


\section{APPENDIX B - Self-identified Non-religious Label}

\section{Self-identified non-religious label}

Which of the following non-religious labels most closely fits your beliefs?

○ Religious - I do believe in God

- Spiritual non-religious - I do not believe in the traditional God, but I do believe in some form of a higher power

- Agnostic - I'm not sure if there is a God, gods, or a higher power

$\circ$ Atheist - I do not believe in God, gods, or any higher power 


\section{APPENDIX C - The Calling and Vocation Questionnaire \\ The Calling and Vocation Questionnaire}

Please indicate the degree to which you believe the following statements describe you, using the following scale. Please respond with your career as a whole in mind. For example, if you are currently working part time in a job that you don't consider part of your career, focus on your career as a whole and not your current job. Try not to respond merely as you think you "should" respond; rather, try to be as accurate and as objective as possible in evaluating yourself. If any of the questions simply do not seem relevant to you, "1" may be the most appropriate answer.

$1=$ Not at all true of me $\quad 2=$ Somewhat true of me

$3=$ Mostly true of me $\quad 4=$ Absolutely true of me

1. I believe that I have been called to my current line of work.

2. I'm searching for my calling in my career.

3. My work helps me live out my life's purpose.

4. I am looking for work that will help me live out my life's purpose.

5. I am trying to find a career that ultimately makes the world a better place.

6. I intend to construct a career that will give my life meaning.

7. I want to find a job that meets some of society's needs.

8. I do not believe that a force beyond myself has helped guide me to my career.

9. The most important aspect of my career is its role in helping to meet the needs of others.

10. I am trying to build a career that benefits society.

11. I was drawn by something beyond myself to pursue my current line of work. 
12. Making a difference for others is the primary motivation in my career.

13. I yearn for a sense of calling in my career.

14. Eventually, I hope my career will align with my purpose in life.

15. I see my career as a path to purpose in life.

16. I am looking for a job where my career clearly benefits others.

17. My work contributes to the common good.

18. I am trying to figure out what my calling is in the context of my career.

19. I'm trying to identify the area of work I was meant to pursue.

20. My career is an important part of my life's meaning.

21. I want to pursue a career that is a good fit with the reason for my existence.

22. I am always trying to evaluate how beneficial my work is to others.

23. I am pursuing my current line of work because I believe I have been called to do so.

24. I try to live out my life purpose when I am at work.

Scoring instructions (items listed should be summed):

CVQ-Presence-Transcendent Summons 1, 8-reverse coded, 11, 23

CVQ-Search-Transcendent Summons 2, 13, 18, 19

CVQ-Presence-Purposeful Work 3, 15, 20, 24

CVQ-Search-Purposeful Work 4, 6, 14, 21

CVQ-Presence-Prosocial Orientation 9, 12, 17, 22

CVQ-Search-Prosocial Orientation 5, 7, 10, 16

CVQ-Presence total 1, 3, 8-reverse coded, 9, 11, 12, 15, 17, 20, 22, 23, 24

CVQ-Search total 2, 4, 5, 6, 7, 10, 13, 14, 16, 18, 19, 21 


\section{APPENDIX D - Person-Organization fit \\ Person-Organization Fit}

Please use the following to scale to indicate the extent to which the values of your organization match your own values.

$1=$ To a very little extent

$2=$ To a small extent

$3=$ To an average extent

$4=$ To a large extent

$5=$ to a very large extent

1. To what extent what extent does your organization measure up to the kind of organization you were seeking?

2. To what extent are the values of the organization similar to your own values?

3. To what extent does the organization fulfill your needs?

4. To what extent is the organization a good match for you? 


\section{APPENDIX E - Job Satisfaction}

\section{Job Satisfaction}

Using the following scale, please indicate how closely each statement fits your feelings toward your current job on a scale from $1-10$ with 1 indicating that you completely disagree with the statement and 10 indicating that the statement reflects your feelings perfectly.

$1=$ strongly disagree $-10=$ Strongly agree

1. "I feel fairly well satisfied with my present job,"

2. "Most days I am enthusiastic about my work,"

3. $\quad$ "Each day of work seems like it will never end" (reverse scored),

4. $\quad$ "I find real enjoyment in my work," and

5. "I consider my job rather unpleasant" (reverse scored) 
APPENDIX F - Microaggressions Against Non-religious Individuals Scale Microaggressions Against Non-religious Individuals Scale (MANRIS)

Please indicate how often you have experienced the following in the last 6 months.

Scale:

$1=$ Never

$2=1-3$ times

$3=4-6$ times

$4=7-9$ times

$5=10$ or more times

F1: Assumption of Inferiority

1. Others have assumed that I would be selfish because of my lack of religion

2. Others have devalued my contributions because of my non-religious background

3. Others have assumed that I am untrustworthy because of my lack of religion

4. Others have assumed that I would not be helpful to another person because of my lack of religion

5. Others have assumed I have less valuable things to say because of my lack of religion

6. Others have dismissed my contributions because of my non-religious background 7. Others have assumed that I would cheat on my work because of my lack of religion

8. Others have assumed that I don't know right from wrong because of my lack of religion

9. Others have assumed I have no morals because of my lack of religion 
F2: Denial of Non-religious Prejudice

1. Others have suggested that I should not complain about non-religious discrimination

2. Others have denied that non-religious people face extra obstacles when compared to others

3. Others have dismissed my experiences as a non-religious individual to be an overreaction

4. Others have suggested that I am too sensitive about discrimination against nonreligious people

5. Others have told me to not complain about my experiences as a non-religious individual

6. Others have suggested that people do not experience non-religious discrimination anymore

7. Others have suggested that my negative experiences as a non-religious individual do not compare to the negative experiences of religious individuals

F3: Assumptions of Religiosity

1. Others have assumed that I am religious

2. Others have assumed I attend places of worship without first asking if I am religious

3. Others have included a blessing or prayer in a public social gathering (e.g., a public business meeting)

4. Others have told me to express thanks to God or Gods for an event

5. Others have acted surprised that I do not believe in God or Gods 


\section{F4: Endorsing Non-religious Stereotypes}

1. Others have assumed that all people in my non-religious group are all the same

2. Others have acted as if all non-religious people are alike

3. Others have suggested that non-religious people think they are better than everyone

4. Others have suggested that non-religious people are not willing to accept others' viewpoints

5. Others have suggested that non-religious people are self-centered

6. Others have asked why non-religious people are intolerant

F5: Pathology of a Non-religious Identity

1. Others have teased me because of my non-religious identity

2. Others have made fun of my non-religious identity

3. Others have made demeaning jokes about my non-religious identity

4. Others have called me names because of my non-religious identity 
APPENDIX G - IRB Approval Letter

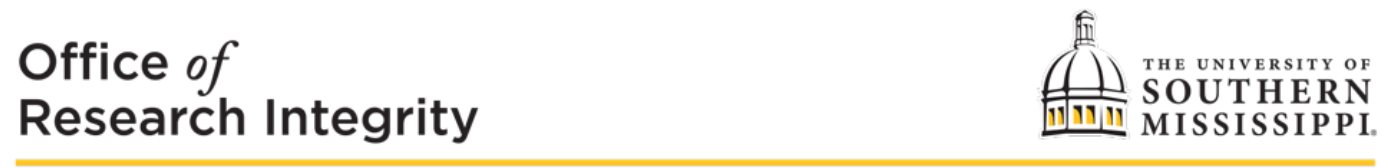

118 COLLEGE DRIVE \#5125 • HATTIESBURG, MS | 601.266.6576 | USM.EDU/ORI

\section{NOTICE OF INSTITUTIONAL REVIEW BOARD ACTION}

The project below has been reviewed by The University of Southern Mississippi Institutional Review Board in accordance with Federal Drug Administration regulations (21 CFR 26, 111), Department of Health and Human Services regulations (45 CFR Part 46), and University Policy to ensure:

- The risks to subjects are minimized and reasonable in relation to the anticipated benefits.

- The selection of subjects is equitable.

- Informed consent is adequate and appropriately documented.

- Where appropriate, the research plan makes adequate provisions for monitoring the data collected to ensure the safety of the subjects.

- Where appropriate, there are adequate provisions to protect the privacy of subjects and to maintain the confidentiality of all data.

- Appropriate additional safeguards have been included to protect vulnerable subjects.

- Any unanticipated, serious, or continuing problems encountered involving risks to subjects must be reported immediately. Problems should be reported to ORI via the Incident template on Cayuse IRB.

- The period of approval is twelve months. An application for renewal must be submitted for projects exceeding twelve months.

PROTOCOL NUMBER: IRB-19-222

PROJECT TITLE: Non-Religious employees' perceptions of microaggressions and their relationship to job satisfaction as moderated by calling SCHOOL/PROGRAM: School of Psychology, Psychology 
RESEARCHER(S): Jessica Schultz, Melanie Leuty

IRB COMMITTEE ACTION: Exempt

CATEGORY: Expedited

Category 2.(i). Research that only includes interactions

involving educational tests (cognitive, diagnostic, aptitude, achievement), survey

procedures, interview procedures, or observation of public behavior (including

visual or auditory recording).

The information obtained is recorded by the investigator in such a manner that the identity of the human subjects cannot readily be ascertained, directly or through identifiers linked to the subjects.

PERIOD OF APPROVAL: June 4, 2019 to June 3, 2020

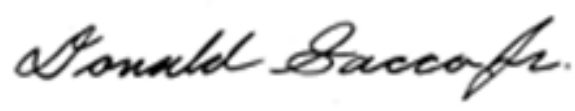

Donald Sacco, Ph.D.

Institutional Review Board Chairperson 


\section{REFERENCES}

Allan, B. A., Tebbe, E. A., Duffy, R. D., \& Autin, K. L. (2014). Living a calling, life satisfaction, and workplace climate among a lesbian, gay and bisexual population. The Career Development Quarterly, 63, 306-319. doi:10.1002/cdq.12030

Baseford, T. E., Offermann, L. R., \& Behrend, T. S. (2014). Do you see what I see? Perceptions of gender microaggressions in the workplace. Psychology of Women Quarterly, 38(3), doi:10.1177/0361684313511420

Bilsky, W., \& Schwartz, S. H. (1994). Values and personality. European Journal of Personality, 8(3), 163-181.

Caldwell-Harris, C. L., Wilson, A. L., LoTempio, E., \& Beit-Hallahmi, B. (2011). Exploring the atheist personality: well-being, awe, and magical thinking in atheists, Buddists, and Christians. Mental Health, Religion \& Culture. 14(7), 659672. doi:10.1080/13674676.2010.509847

Cheng, Z. H., Pagano, L. A., \& Shariff, A. F. (2018). The development and validation of the microaggressions against non-religious individuals scale (MANRIS). Psychology of Religion and Spirituality, 10(3), 254-262. doi:10.1037/rel0000203

Cliteur, P. (2009). The definition of atheism. Journal of Religion and Society, 11, 1-23.

Cragun, R.T., Hammer, J. H., Nielsen, M., \& Autz, N. (2018). Religious/secular distance: how far apart are teenagers from their parents? Psychology of Religion and Spirituality, 10(3), 288-295. doi:10.1037/rel0000205

Creed, P. A., Rogers, M., Praskova, A., \& Searle, J. (2014). Career calling as a personal resource moderator between environmental demands and burnout in junior doctors. Journal of Career Development, 41, 547-561. 
doi:10.1177/0894845313520493Davidson, J. C., \& Caddell, D. P. (1994).

Religion and the meaning of work. Journal for the Scientific Study of Religion,

33, 135-147. doi:102307/1386600

Dawis, R. V. (2005). The Minnesota Theory of Work Adjustment. In S. D. Brown \& R.W. Lent (Eds.), Career development and counseling: Putting theory and research to work (pp. 3-23). Hoboken, N.J.: John Wiley and Sons, Inc.

Dik, B. J., \& Duffy, R. D. (2009). Calling and vocation at work: definitions and prospects for research and practice. The Counseling Psychologist, 37, 424-450

Dik, B. J., Duffy, R. D., \& Eldridge, B. M. (2009). Calling and vocation in career counseling: Recommendations for promoting meaningful work. Professional Psychology: Research and Practice, 40, 625-

632. https://doi.org/10.1037/a0015547

Dik, B. J., Eldridge, B. M., Steger, M. F., \& Duffy, R. D. (2012). Development and validation of the calling and vocation questionnaire (CVQ) and brief calling scale (BCS). Journal of Career Assessment, 20(3), 242-263.

doi: $10.1177 / 1069072711434410$

Dik B. J., Reed K., Shimizu A. B., Marsh D. R., \& Morse J. L. (2019) Career callings and career Development. In J. Athanasou \& H. Perera (Eds) International Handbook of Career Guidance (p. 185-206). Cham, Switzerland: Springer.

Dik, B. J., Sargent, A. M., \& Steger, M. F. (2008). Career development strivings: assessing goals and motivation in career decision- making and planning. Journal of Career Development, 35, 23-41, doi:10.1177/0894845308317934 
Dik, B. J., \& Steger, M. F. (2008). Randomized trial of a calling-infused career workshop incorporating counselor self-disclosure. Journal of Vocational Behavior, 73(2), 203-211.

Doane, M. J. \& Elliott, M. (2015). Perceptions of discrimination among atheists: consequences for atheist identification, psychological and physical well-being. Psychology of Religion and Spirituality, 7(2), 130-141. doi:10.1037/rel0000015

Duffy, R. D., Allan, B. A., Bott, E. M. (2011). Calling and life satisfaction among undergraduate students: investigating mediators and moderators. Journal of Happiness Studies, 13, 469-479. doi: 10.107/s10902-011-9274-6

Duffy, R. D., Allan, B. A., \& Dik, B. J. (2011). The presence of calling and academic satisfaction: exploring potential mediators. Journal of Vocational Behavior, 79, 74-80. doi:10.1016/j.jvb.2010.11..00

Duffy, R. D., Allan, B. A., Autin, K. L., \& Douglas, R. P. (2014). Living a calling and work well-being: a longitudinal study. Journal of Counseling Psychology, 61(4), 605-615. doi:10.1037/cou0000042

Duffy, R. D., Bott, E. M., Allan, B. A., Torrey, C. L., Dik, B. J. (2012). Perceiving calling, living a calling, and job satisfaction: testing a moderated, multiple mediator model. Journal of Counseling Psychology, 59(1), 50-59. doi:10.1037/a0026129

Duffy, R. D., Bott, E. M., Torrey, C. L., \& Webster, G. W. (2013). Work volition as a critical moderator in the prediction of job satisfaction. Journal of Career Assessment, 21(1), 20-31. doi:10.1177/1069072712453831 
Duffy, R. D., \& Dik, B. J. (2013). Research on calling: what have we learned and where are we going? Journal of Vocational Behavior, 83, 428-436.

Duffy, R. D., \& Sedacek, W. E. (2007). The presence of and search for calling: connections to career development. Journal of Vocational Behavior, 70, 590-601. doi:10.1016/j.jvb.2007.03.007

Duffy, R. D., \& Sedalek, W. E. (2010). The salience of career calling among college students: exploring group differences and links to religiousness, life meaning, and life satisfaction. The Career Development Quarterly, 59, 27-41. doi:10.1002/j.21610045.2010.tb00128.x.

Galen, L. W. \& Kloet, J. D. (2011). Mental well-being in the religious and the nonreligious: evidence for a curvilinear relationship. Mental Health, Religion \& Culture, 14(7), 673-689. doi:10.1080/13674676.2010.510829

Greguras, G. J. \& Diefendorff, J. M. (2009). Different fits satisfy different needs: Linking person-environment fit to employee commitment and performance using selfdetermination theory. Journal of Applied Psychology, 94(2), 465-477.

Hall, S. F., Burkholder, D., \& Sterner, W. R. (2014). Examining spirituality and sense of calling in counseling students. Counseling and Values, 59, 3-16. doi:10.1002/j.2161-007x.2014.00038.x

Hayward, R. D., Krause, N., Ironson, G., Hill, P. C., \& Emmons, R. (2016). Health and well-being among the non-religious: atheists, agnostics, and no-preference compared with religious group members. Journal of Religious Health, 55, 10241037. doi:10.1007/s10943-015-0179-2 
Hirschi, A. (2012). Callings and work engagement: Moderated mediation model of work meaningfulness, occupational identity, and occupational self-efficacy. Journal of Counseling Psychology, 59, 479-485. doi:10.1037/a0028949

Hirschi, A. \& Hermann, A. (2013). Calling and career preparation: Investigation developmental patterns and temporal precedence. Journal of Vocational Behavior, 83, 51-60. doi:10.1016/j.jvb.2013.02.008

Holder, A. M. B., Jackson, M. A., \& Ponterotto, J. G. (2015). Racial microaggression experiences and coping strategies of black women in corporate leadership. Qualitative Psychology, 2(2), 164-180. doi:10.1037/qup0000024

Hovarth, M. (2015). Predicting work outcomes from religiosity and perceived calling. The Career Development Quarterly, 63, 141-155. doi:10.1002/cdq.12010

Hunter, J. A. (2001). Self-esteem and in-group bias among members of a religious social category. The Journal of Social Psychology, 141(3), 401-411.

IBM Corp. Released 2017. IBM SPSS Statistics for Windows, Version 25.0. Armonk, NY: IBM Corp.

Judge, T. A., \& Bono, J. E. (2001). Relationship of core self-evaluations traits - selfesteem, generalized self-efficacy, locus of control, and emotional stability - with job satisfaction and job performance. Journal of Applied Psychology, 86(1), 8092. doi:10.1037//0021-9010.86.1.80

Judge, T. A., \& Kristof-Brown, A. (2004). Personality, interactional psychology, and person-organization fit. In B. Schneider \& D. B. Smith (Eds.), Personality and organizations: 87-109. Mahwah, NJ: Erlbaum 
Judge, T. A., Locke, E. A., Durham, C. C., \& Kluger, A. N. (1998). Dispositional effects on job and life satisfaction: the role of core evaluations. Journal of Applied Psychology, 83(1), 17-34.

Keller, B., Bullik, R., Klein, C., \& Swanson, S. B. (2018). Profiling atheist world views in different cultural contexts. Psychology of Religion and Spirituality, 10(3), 229243. doi:10.1037/rel0000212

Kristoff-Brown, A. L., Zimmerman, R. D., Johnson, E. C. (2005). Consequences of individuals' fit at work: A meta-analysis of person-job, person-organization, person-group, and person-supervisor fit. Personnel Psychology, 58(2), 281-342.

Lewis, R. J., Derlega, V. J., Griffin, J. L., \& Krowinski, A. C. (2003). Stressors for gay men and lesbians: Life stress, gay-related stress, stigma consciousness, and depressive symptoms. Journal of Social and Clinical Psychology, 22(6), 716-729. doi:10.1521/jscp.22.6.716.22932

Leuty, M. E., \& Hansen, J. C. (2011). Evidence of construct validity for work values. Journal of Vocational Behavior, 79, 379-390. doi:10.1016/j.jvb.2011.04.008

Lovelace, K., \& Rosen, B. (1996). Differences in achieving person-organization fit among diverse groups of managers. Journal of Management, 22, 703-722. doi:10.1177/014920639602200502

Lyons, H. Z., \& O'Brien, K. M. (2006). The role of person-environment fit in the job satisfaction and tenure intentions of African American employees. Journal of Counseling Psychology, 53, 387-396. doi:10.1037/0022-0167.53.4.387 
Lyons, H. Z., Velez, B. L., Mehta, M., \& Neil, N. (2014). The Theory of Work Adjustment with economically distressed African Americans. Journal of Counseling Psychology, 61(3), 473-483. doi:10.1037/cou0000017

Martinez, L. R., Sawyer, K. B., Thouroughgood, C. N., Ruggs, E. N., \& Smith, N. A. (2017). The importance of being "me:" the relationship between authentic identity expression and transgender employee work-related attitudes and experiences. Journal of Applied Psychology, 102(2), 215-226. doi:10.1037/ap10000168

Nadal, K. L. (2011). The racial and ethnic microaggressions scale (REMS): Construction, reliability, and validity. Journal of Counseling Psychology, 58, 470-480. doi:10.1037/ a0025193

Nadal, K. L., Davidoff, K. C., Davis, L. S., Wong, Y., Marshall, D., Mckenzie, V. (2015). A qualitative approach to intersectional microaggressions: Understanding influences of race, ethnicity, gender, sexuality, and religion. Qualitative Psychology, 2(2), 147-163. doi:10.1037/qup0000026

Nadal, K. L., Griffin, K. E., Hamit, S., Leon, J., Tobio, M., Rivera, D. P. (2012). Subtle and overt forms of islamophobia: microaggressions toward Muslim Americans. Journal of Muslim Mental Health, 6(2), 15-37. doi:10381607.0006.203

Nadal, K. L., Griffin, K. E., Wong, Y., Hamit, S., \& Rasmus, M. (2014). The impact of racial microaggressions on mental health: Counseling implications for clients of color. Journal of Counseling \& Development, 92, 57-66. doi:10.1002/j.15566676.2014.00130.x

Nadal, K. L., Issa, M., Griffin, K.E., Hamit, S., Lyons, O. B. (2010) Religious microaggressions in the United States: mental health implications for religious 
minority groups. In D. W. Sue (Ed.), Microaggressions and Marginality:

Manifestation, Dynamics, and Impact (pp. 287-310). Hoboken, NJ: John Wiley \& Sons.

Nadal, K. L., Wong, Y., Griffin, K. E., Davidoff, K., Sriken, J. (2014). The adverse impact of racial microaggressions on college students' self-esteem. Journal of College Student Development, 55(5), 461-474. doi:10.1353/csd.2014.0051

Neubert, M. J., \& Halbesleben, K. (2015). Calling to commitment: An examination of relationships between spiritual calling, job satisfaction, and organizational commitment. Journal of Business Ethics, 132, 859-872. doi:10.1007/s10551-0142336-z

Pew Research Center. (2014). America's changing religious landscape (p. 201). Washington, DC: Pew Research Center. http://www.pewforum.org/2015/05/12/americas-changing-religious-landscape/

Ponton, R., Brown, T., McDonnell, B., Clark, C., Pepe, J., \& Deykerhoff, M. (2014). Vocational perception: A mixed-method investigation of calling. The Psychologist Manager Journal, 17(3), 182-204. doi:10.1037/mgr0000019

Resick, C. J., Baltes, B. B., \& Walker Shantz, C. (2007). Person-organization fit and work-related attitudes and decisions: Examining interactive effects with job fit and conscientiousness. Journal of Applied Psychology, 92(5), 1446-1455. doi:10.1037/0021-9010.92.5.1446

Salvatore, J. \& Shelton, J. N. (2007). Cognitive costs of exposure to racial prejudice. Psychological Science, 18, 810-815. 
Saks, A. M., \& Ashforth, B. E. (1997). A longitudinal investigation of the relationships between job information sources, applicant perceptions of fit, and work outcomes. Personnel Psychology, 50(2), 395-426.

Schnell, T. (2015). Dimensions of secularity (DoS): an open inventory to measure facets of secular identities. The International Journal for the Psychology of Religion, 25, 272-292. doi:10.1080/10508619.2014.967541

Sherkat, D. E. (2008). Beyond belief: atheism, agnosticism, and theistic certainty in the United States. Sociological Spectrum, 28, 438-459. doi:10.1080/02732170802205932

Steger, M. F., Pickering, N., Shin, J. Y., \& Dik, B. J. (2010). Calling in work: Secular or sacred? Journal of Career Assessment, 18, 82-96. doi:10.1177/1069072709350905

Strosser, G. L., Jonason, P.K., Lawson, R., Reid, A. N., \& Vittum-Jones, A. W. (2016). When private reporting is more positive than public reporting: pluralistic ignorance towards atheists. Social Psychology, 47(3), 150-162. doi:10.1027/18649335/a000267

Twenge, J. M. (2010). A review of the empirical evidence on generational differences in work attitudes. Journal of Business and Psychology, 25(2), 201-210.

Velez, B. L., \& Moradi, B. (2012). Workplace support, discrimination, and personorganization fit: Tests of the Theory of Work Adjustment with LGB individuals. Journal of Counseling Psychology, 59(3), 399-407. doi:10.1037/a0028326 
Wrzesniewski, A., McCauley, C., Rozin, P., \& Schwartz, B. (1997). Jobs, careers, and callings: People's relations to their work. Journal of Research in Personality ,31, 21-33, doi:10.1006/jrpe.1997.2162 